\title{
Finnish Spitz
}

National Cancer Institute

\section{Source}

National Cancer Institute. Finnish Spitz. NCI Thesaurus. Code C53853.

The Finnish Spitz resembles a fox with a pointed muzzle, perked ears. It has thick, erect, medium-length hair with a thick under-layer of straight hair. Its plumed tail curls up over the back and down the side. The feet are round and cat-like. The coat color may be redbrown, or a yellowish-red with some white markings. Height: 15-20 inches $(38-51 \mathrm{~cm}$.) Weight: $31-35$ pounds (14-16 kg.) 